\title{
SPACE VECTOR PULSE WIDTH MODULATION OF FOUR-SWITCH VOLTAGE SOURCE INVERTER FEEDING THREE PHASE INDUCTION MOTOR
}

\author{
G. M. A. Sowilam ${ }^{1,2}$ and Haitham Z. Azazi ${ }^{3}$ \\ sowilam@yahoo.com, \\ ${ }^{1}$ Electrical Power \& Machine Engineering Department, Faculty of Engineering, Helwan \\ University \\ ${ }^{2}$ Electrical Engineering Department, Faculty of Engineering \&Islamic Architecture, UQU \\ university \\ ${ }^{3}$ Department of Electrical Engineering, Faculty of Engineering, Menoufia University, Egypt
}

\begin{abstract}
:
An analytical model with a new space vector pulse width modulation Voltage source inverter technique method of four-switch three-phase inverter (FSVPWM) feeding induction motor is presented. This paper presents a low cost inverter employing only four switches, four diodes and a split capacitor bank in the dc-link. This work is motivated by the need of an efficient and flexible modulation method, which is optimized with respect to minimum electrical motor torque. The proposed modulation strategy for the four-switch operation has the same symmetry as in a classical six-switches space vector pulse width modulation inverter (SSVPWM). The common mode voltage generated by the four-switch space vector pulse width modulation three-phase converter is evaluated and compared to that provided by the standard six-switch space vector pulse width modulation threephase inverter. Simulation result are presented to demonstrate the feasibility of the proposed approach.
\end{abstract}

\section{Index Terms :}

Three-phase Induction motors, FSVPWM, Classical SSVPWM, modeling, Matlab/Simulink and timedomain analysis.

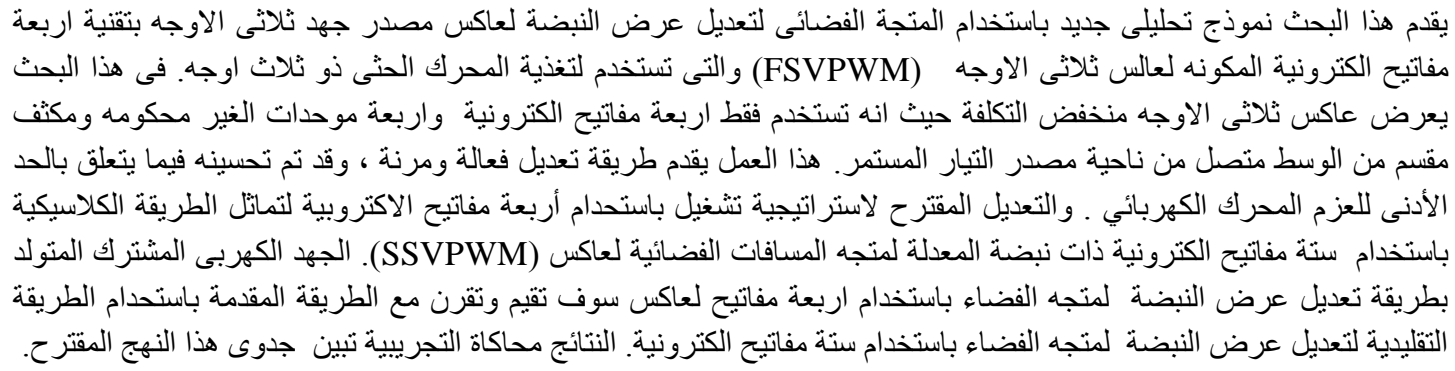

\section{INTRODUCTION}

Improvements in power semiconductor switching technology have significantly reduced the cost and size of ac drives and improved waveform quality. Recently there has been growing interest in low cost ac drives to meet the needs for reducing cost. A number of low cost topologies have been suggested for single-phase to three-phase[1-6] or three-phase to three-phase voltage source inverter[7-9]. There are a variety of names for these inverters, i.e. inverter system with a reduced switch count, component minimized or four-switches inverter, split capacitor dc link inverter, and four switch three-phase inverter.

Van der Broecket. al. suggested a method of generating the three-phase waveforms with two dc link voltages and discussed the harmonic effects [1-2]. The modulation strategy suggested can produce three phase

Engineering Research Journal, Vol. 39, No. 1, January 2016, PP: 241-250

(C) Faculty of Engineering, Menoufiya University, Egypt 
balanced sinusoidal waveforms at a reduced output voltage of 0.866 compared with the conventional six switch inverter. In another topology proposed by Enjetiet. al., the diode bridge rectifier is replaced by a single-phase current controlled rectifier employing two switches and two capacitors[4-5]. Covicet. al. proposed the new voltage control scheme, which enables unity power factor and an improved dc link voltage control independent of input voltage fluctuations[6]. However, the single-phase rectifier has a limitation for high power applications because power flow is not constant, therefore, requires a much larger capacitance in the dc link, which makes system performance sluggish. G. T. Kim et. al. proposed a three-phase to three-phase VSI-PWM rectifier and inverter structure with eight switches, and discussed feasibility and operational limitations of the proposed structure[7]. M. Nasir Uddinet. al. presented a cost effective drive system for a salient pole permanent magnet synchronous motor for high performance industrial drive system. The proposed approach utilized a 4-switch 3-phase inverter instead of a conventional 6-switch 3-phase inverter [10]. This reduced both the cost of the inverter and the computation for real-time implementation. J. klima presented analytical investigation of an induction motor fed fron fourswitch VSI with a new space vector modulation strategy [11]. The analytical results of the machine are accomplished in an $\alpha \beta$ complex plane by space vector decomposition and using mixed $\mathrm{p}-\mathrm{z}$ approach. $\mathrm{M}$. Azabet. al. presented a control method for 4-switch three-phase inverter suitable for low power applications [12]. A suitable switching table has been derived which selects the inverter switching states to fulfill the torque and flux requirements. H. H. Lee, et. al. present space vector control approach for four-switch three-phase inverter under Dc-link voltage ripple imbalance in photovoltaic or fuel cell inverter technology [13]. Space vector PWM technique for FSTPI under DC-link voltage imbalance or ripples have been solved, which is based on the establishment of basic space vectors and modulation technique in similarity with six-switch three-phase inverter.

In spite of the four-switches inverter drawbacks like a higher DC-link capacitor voltage and unsymmetrical scheme exposed to the unbalanced capacitor voltage, this inverter has the following advantages over six-switches inverter[14]:

- The number of switches is reduced by a third; driving circuits are only two as only two branches are controlled.

- In spite of the switch's higher withstand-able voltage in four-switches inverter the cost is still lower thanks to the price ratio of fourswitches inverter to six-switches inverter usually lower than $3 / 2$.

- Four-switches inverter maximum common mode voltage is just $2 / 3$ of six-switches inverter.

This paper presents a new technique to generate space-vector pulse width modulation SVPWM signals for control of the four-switch, three-phase voltage source inverter based on principal of SVPWM. The analysis of this system under this technique will be discussed. the comparison between the two techniques (four switches and six switches) of SVPWM will carried out.

The proposed structure uses four diodes for rectifier, four power switches (IGBT) for inverter and two split-capacitor dc high voltage link as shown in Fig. 1. the four-switch inverter provide two of the inverter output phases. the third phase is fed by the dc link from the center of a split-capacitor bank.

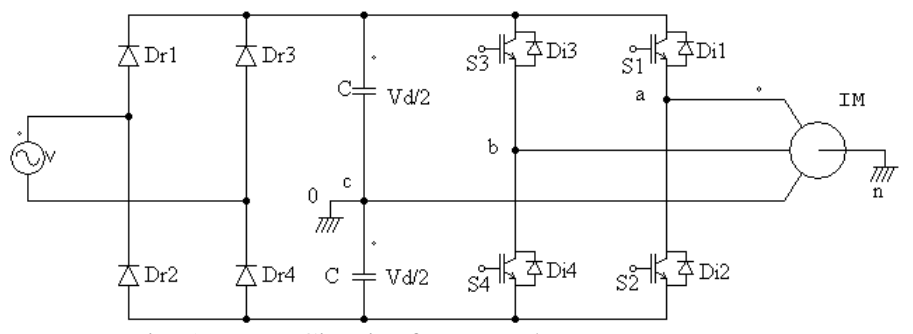

Fig. 1 Power Circuit of proposed system.

\section{Analysis of space voltage pulse width modulation}

With respect to the circuit of Fig. 1, the phase and line voltages at the three-phase load terminals depend on the conduction states of the power switches. When the switches status are set to "1" when the power switch is closed and "0" when open. In addition the switches in one inverter branch are controlled complementary, therefore:

$S_{1}+S_{3}=1$ and $S_{3}+S_{4}=1$

The phase voltage between $\mathrm{a}, \mathrm{b}$ and $\mathrm{c}$ to the point " 0 " are given by:

$$
\begin{gathered}
v_{a 0}=v_{a n}-v_{c n}, v_{b 0}=v_{b n}-v_{c n} \text { and } v_{c 0}=0 \\
v_{a 0}=\left(2 S_{1}-1\right) \frac{V_{d}}{2} \text { and } v_{b 0}=\left(2 S_{3}-1\right) \frac{V_{d}}{2}
\end{gathered}
$$

The phase voltage across motor, between $a, b$ and $c$ to the point " $n$ " are given by:

$v_{a n}=\frac{V_{d}}{6}\left[4 S_{1}-2 S_{3}-1\right], \quad v_{b n}=\frac{V_{d}}{6}\left[4 S_{3}-2 S_{1}-1\right]$

and 


$$
v_{c n}=-\frac{v_{d}}{3}\left[S_{1}+S_{2}-1\right]
$$

The resultant space vector of the inverter output voltage is calculated using the following equations:

$$
\begin{aligned}
& v_{i}=\frac{2}{3}\left(v_{a n}+a v_{b n}+a^{2} v_{c n}\right)=\frac{2}{3}\left(v_{\alpha}+j v_{\beta}\right) a= \\
& e^{-j 2 \pi / 3} \text { and }^{2}=e^{j 2 \pi / 3}
\end{aligned}
$$

Thus the orthogonal components voltage is given by:

$$
\begin{gathered}
v_{\alpha}=\frac{2}{3}\left[v_{a n}-0.5 v_{b n}-0.5 v_{c n}\right] \text { and } \\
v_{\beta}=\frac{1}{\sqrt{3}}\left[v_{b n}-v_{c n}\right]
\end{gathered}
$$

Table I shows the simplified of switching status, phasezero voltage, phase voltage to neutral and the component $\left(v_{\alpha}\right.$ and $v_{\beta}$ ), space vector voltage $v_{i}$ and its angle $\left({ }_{i}^{\theta}\right)$, where $\mathrm{i}=1,2,3$ and 4 .

Table I shows the Simplified of switching status, phase-zero voltage, phase voltage to neutral and the component $\left(v_{\alpha}\right.$ and $\left.v_{\beta}\right)$, space vector voltage $v_{i}$ and its angle $\left({ }_{i}{ }_{i}\right)$, where $\mathrm{i}=1,2,3$ and 4 .

Fig. 2 shows the Voltage space vector in the plan $\alpha \beta$.

Table I. Simplified of switching status, the corresponding voltages.

\begin{tabular}{|c|c|c|c|c|c|c|c|c|c|c|c|}
\hline$S_{a}$ & $S_{b}$ & $v_{a 0}$ & $v_{b 0}$ & $v_{c 0}$ & $v_{a n}$ & $v_{b n}$ & $v_{c n}$ & $v_{a}$ & $v_{\beta}$ & $v_{i}$ & $A n g l e_{i}$ \\
\hline 0 & 0 & $-V_{d} / 2$ & $-V_{d} / 2$ & 0 & $-V_{d} / 6$ & $-V_{d} / 6$ & $+V_{d} / 3$ & $-V_{d} / 6$ & $-V_{d} /(2 \sqrt{3})$ & $V_{d} / 3$ & 240 \\
\hline 0 & 1 & $-V_{d} / 2$ & $+V_{d} / 2$ & 0 & $-V_{d} / 2$ & $+V_{d} / 2$ & 0 & $-V_{d} / 2$ & $+V_{d} /(2 \sqrt{3})$ & $V_{d} / \sqrt{3}$ & 150 \\
\hline 1 & 0 & $+V_{d} / 2$ & $-V_{d} / 2$ & 0 & $+V_{d} / 2$ & $-V_{d} / 2$ & 0 & $+V_{d} / 2$ & $-V_{d} /(2 \sqrt{3})$ & $V_{d} / \sqrt{3}$ & 330 \\
\hline 1 & 1 & $+V_{d} / 2$ & $+V_{d} / 2$ & 0 & $+V_{d} / 6$ & $+V_{d} / 6$ & $-V_{d} / 3$ & $+V_{d} / 6$ & $+V_{d} /(2 \sqrt{3})$ & $V_{d} / 3$ & 60 \\
\hline
\end{tabular}

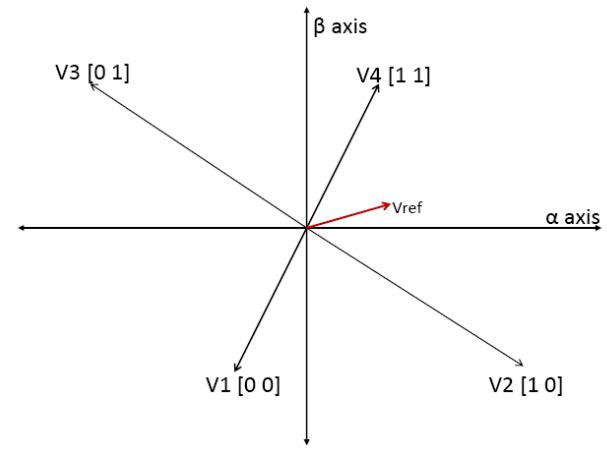

Fig. 2 Space vector voltage in the plan $\alpha \beta$.

The flux linkage vector of three-phase induction motor can be represented as [14]:

$$
\bar{\varphi}=\int v_{i}(t) d t
$$

When the four-switch inverter fed the motor, the flux linkage vector becomes:

$$
\overline{\varphi_{l}}=t_{i} \cdot \overline{v_{l}}+\overline{\varphi_{0}}
$$

where $i=1$ to 4 ; and $t_{i}$ is the duration of $v_{i}$. If the switching algorithms can ensure the best approximation by minimizing the discrepancy between vector loci $\bar{\varphi}$ and $\overline{\varphi^{*}}$, the stator voltage performance will be optimize.

\section{NEW TECHNIQUE OF FSVPWM}

FSVPWM technique proposed in this paper is based on the principle of similarity of four-switch inverter, where $\alpha \beta$-plan is divided into six sectors, instead of four sector, and the formation of $V_{r e f}$ is done similarly as six-switch. Fig. 3 shows the new vectors with aiding the four vector of Fig. 2.

The new vectors:

$\mathrm{V}_{24}$ is resultant of $\mathrm{V}_{2}$ and $\mathrm{V}_{4}$ as shown in Fig. 3,

$\mathrm{V}_{34}$ is resultant of $\mathrm{V}_{3}$ and $\mathrm{V}_{4}$,

$V_{13}$ is the resultant of $V_{1}$ and $V_{3}$ and

$\mathrm{V}_{12}$ is the resultant of $\mathrm{V}_{1}$ and $\mathrm{V}_{2}$.

The mid of the those vector beside of the $V_{1}$ and $V_{4}$ gives the new space vector of four-switch FSVPWM. The zero vector $\mathrm{V}_{0}$ can be obtained by resulting $\mathrm{V}_{4}$ and $\mathrm{V}_{1}$ or by resulting $\mathrm{V}_{3}$ and $\mathrm{V}_{2}$. Those new vectors like the conversional six-switch SVPWM that shown in Fig. 4. Where new vectors

$\mathrm{V}_{24 \mathrm{~m}}=1 / 2 \mathrm{~V}_{24}$ as shown in both Fig. 3 and Fig. 4 .

$\mathrm{V}_{34 \mathrm{~m}}=1 / 2 \mathrm{~V}_{34}$,

$\mathrm{V}_{13 \mathrm{~m}}=1 / 2 \mathrm{~V}_{13}$,

$\mathrm{V}_{12 \mathrm{~m}}=1 / 2 \mathrm{~V}_{12}$ and

$\mathrm{V}_{0 \mathrm{~m}}=\left(\mathrm{V}_{4}+\mathrm{V}_{1}\right) / 2$ or $\left(\mathrm{V}_{3}+\mathrm{V}_{2}\right) / 2$.

Table II shows the relationship and similarity between FSVPWM and the conventional SVPWM.

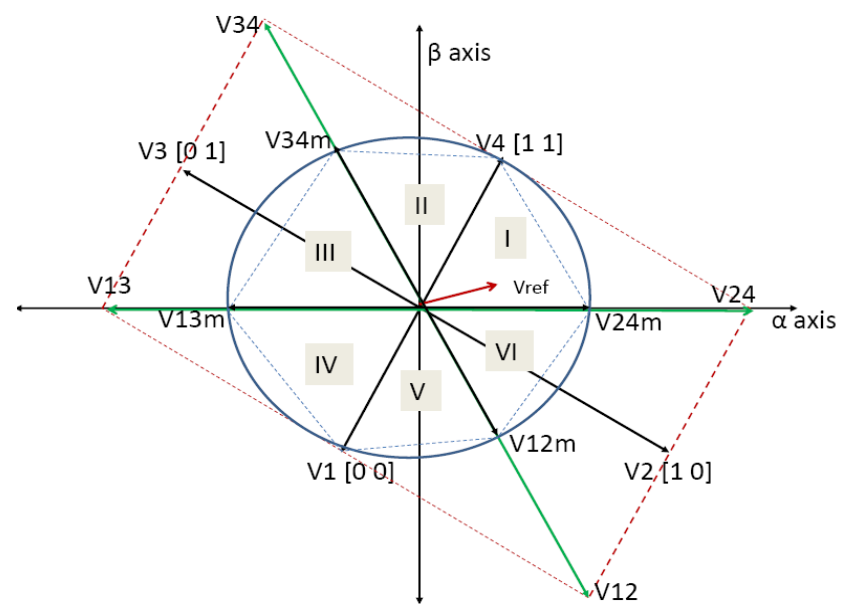

Fig. 3 SVPWM technique of 4-switch on the principle similar to 6-switch. 
The calculation of the switching states in six-switch and four-switch are as follows for $\mathrm{T}_{\mathrm{s}} / 2$ [15-16]. where $\mathrm{T}_{\mathrm{s}}$ is the switching frequency.

$$
\begin{aligned}
& t_{1}=\frac{\sqrt{3}}{\pi} M T_{s} \sin \left(\frac{\pi}{3}-\alpha\right), \\
& \qquad t_{2}=\frac{\sqrt{3}}{\pi} M T_{s} \sin (\alpha) \text { and } \\
& t_{0}=\frac{T_{s}}{2}-t_{1}-t_{2}
\end{aligned}
$$

where $t_{1}$ is the duration for vector $V_{1}, t_{2}$ is the duration for vector $V_{2}$ and $t_{0}$ is the duration of vector $V_{0}$. M is the modulation index $=\mathrm{V}_{\text {ref }}$ /peak voltage of six step voltage and $\mathrm{V}_{\text {ref }}$ is required amplitude of voltage vector.

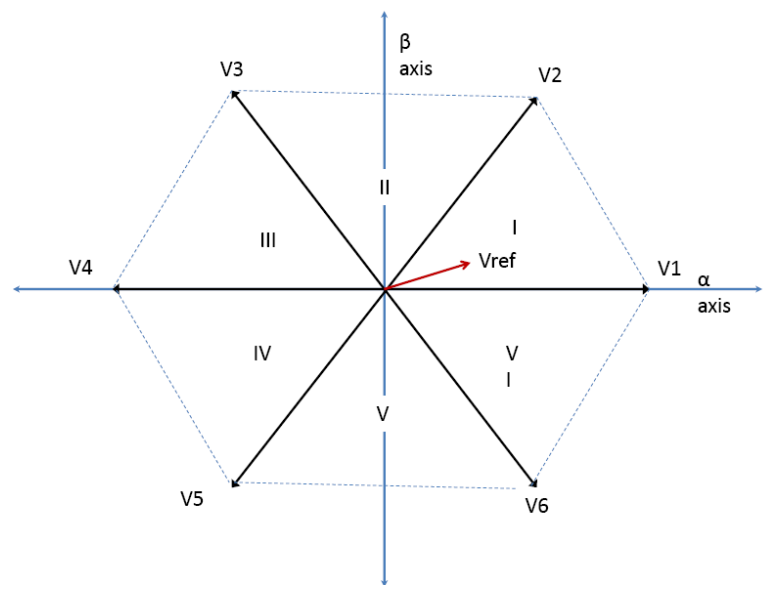

Fig. 4 The conversional six-switch SVPWM.

Table II The similarity of between FSVPWM and the conventional SVPWM

\begin{tabular}{|c|c|}
\hline FSVPWM & conventional SVPWM \\
\hline $\mathrm{V}_{24 \mathrm{~m}}$ & $\mathrm{~V}_{1}$ \\
\hline $\mathrm{V}_{4}$ & $\mathrm{~V}_{2}$ \\
\hline $\mathrm{V}_{34 \mathrm{~m}}$ & $\mathrm{~V}_{3}$ \\
\hline $\mathrm{V}_{13 \mathrm{~m}}$ & $\mathrm{~V}_{4}$ \\
\hline $\mathrm{V}_{1}$ & $\mathrm{~V}_{5}$ \\
\hline $\mathrm{V}_{12 \mathrm{~m}}$ & $\mathrm{~V}_{6}$ \\
\hline $\mathrm{V}_{0}$ & $\mathrm{~V}_{0}$ and $\mathrm{V}_{7}$ \\
\hline
\end{tabular}

For example, in sector I (Fig.3), the effective vectors $\mathrm{V}_{24 \mathrm{~m}}, \mathrm{~V}_{4}$ and $\mathrm{V}_{0}$ are defined as equation (8):

Time duration of vector $\mathrm{V}_{24 \mathrm{~m}}: \mathrm{T}_{1}=\mathrm{t}_{1}$

Time duration of vector $\mathrm{V}_{4}: \mathrm{T}_{2}=\mathrm{t}_{2}$

Time duration of Vector $\mathrm{V}_{0}: \mathrm{T}_{0}=\mathrm{T}_{\mathrm{s}} / 2-\mathrm{T}_{1}-\mathrm{T}_{2}$.

Now the timings of the switching pattern is shown in Fig. 5 can be calculated as:
$\mathrm{T}_{\mathrm{a}}=\mathrm{T}_{0} / 2$ that is equivalent to the switching state [0 $0]$.

$\mathrm{T}_{\mathrm{b}}=\mathrm{T}_{1} / 2$ that is equivalent to the switching state [ 10$]$.

$\mathrm{T}_{\mathrm{c}}=\mathrm{T}_{2}+\mathrm{T}_{1} / 2+\mathrm{T}_{0} / 2$ that is equivalent to the switching state [1 1 1

Where $T_{a}, T_{b}$ and $T_{c}$ represent the time duration of base vector $V_{1}, V_{2}$ and $V_{5}$. Similarly we can calculate the space vector modulation for the other sectors. The calculation results and the switching states are shown in Table III.

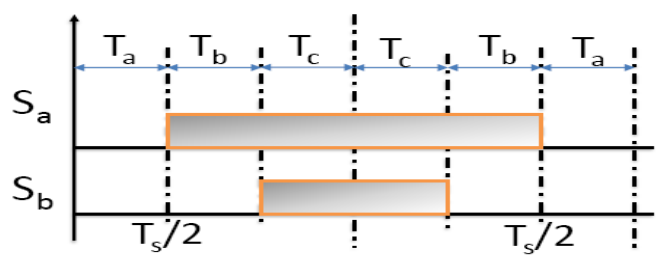

For sector I, V, VI

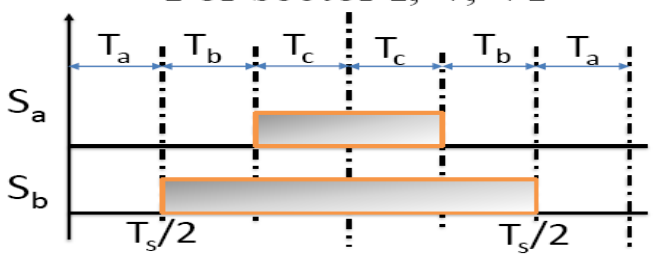

For sector II, III, IV

Fig. 5 Switching states pattern.

\section{Simulation results of the proposed system and comparison with conventional type of SVPWM}

Simulation induction motor drive based on FSVPWM topology are carried out using Matlab/Simulink package. Moreover, to evaluate the performance of the proposed system, induction motor drive by conventional SSVPWM topology is also simulated to make a comparison between both schemes.

Fig. 6 to Fig. 8 shows the simulation results of induction motor using FSVPWM topology. The parameters of motor are listed in Appendix I. The applied ac voltage is $600 \mathrm{~V}$, frequency is $50 \mathrm{~Hz}$ and modulation index is 0.9 . Fig. 6 shows the performance of motor (the three phase motor current, the voltage across phase "a", the speed of motor, motor torque and load torque). The motor is tested with constant load torque equal $10 \mathrm{Nm}$. Fig. 7 shows the flux and the relationship between the flux in d- and q- axes. Fig. 8 shows the spectrum analysis for the stator voltage and current. It is clear that, the current is sinusoidal and the phase shift is $120^{\circ}$.

The results show voltage THD is $5.374 \%$ and current THD is $4.2396 \%$, those values are acceptable for IEEE stander. 
Table III The calculation results of time duration of vectors and the corresponding their switching states.

\begin{tabular}{|c|c|}
\hline Sector I $\left(0-60^{\circ}\right)$ & Sector IV $\left(180^{\circ}-240^{\circ}\right)$ \\
\hline $\begin{array}{l}T_{1}=\frac{\sqrt{3}}{\pi} M T_{s} \sin \left(\frac{\pi}{3}-\alpha\right) \\
T_{\mathbf{2}}=\frac{\sqrt{3}}{\pi} M T_{s} \sin (\alpha) \text { and } \\
T_{0}=\frac{T_{s}}{2}-T_{1}-T_{2} \\
\text { The duration states and } \\
\text { switching states are: } \\
\qquad T_{a}=\frac{T_{0}}{2} \rightarrow\left[\begin{array}{ll}0 & 0\end{array}\right] \\
\qquad T_{b}=\frac{T_{1}}{2} \rightarrow\left[\begin{array}{ll}1 & 0\end{array}\right] \\
T_{c}=\left(T_{2}+\frac{T_{1}}{2}+\frac{T_{0}}{2}\right) \rightarrow[1\end{array}$ & $\begin{array}{l}T_{1}=\frac{\sqrt{3}}{\pi} M T_{s} \sin \left(\frac{\pi}{3}-\alpha\right) \\
T_{2}=\frac{\sqrt{3}}{\pi} M T_{s} \sin (\alpha) \text { and } \\
T_{0}=\frac{T_{s}}{2}-T_{1}-T_{2} \\
\text { The duration states and } \\
\text { switching states are: } \\
T_{a}=\left(T_{2}+\frac{T_{1}}{2}+\frac{T_{0}}{2}\right) \rightarrow[00] \\
\quad T_{b}=\frac{T_{1}}{2} \rightarrow[01] \\
T_{c}=\frac{T_{0}}{2} \rightarrow[11]\end{array}$ \\
\hline Sector II $\left(60^{\circ}-120^{\circ}\right)$ & Sector V $\left(240^{\circ}-300^{\circ}\right)$ \\
\hline $\begin{array}{l}T_{\mathbf{1}}=\frac{\sqrt{3}}{\pi} M T_{s} \sin \left(\frac{\pi}{3}-\alpha\right) \\
\quad ; \\
T_{\mathbf{2}}=\frac{\sqrt{3}}{\pi} M T_{s} \sin (\alpha) \text { and } \\
T_{\mathbf{0}}=\frac{T_{s}}{2}-T_{\mathbf{1}}-T_{\mathbf{2}} \\
\text { The duration states and } \\
\text { switching states are: } \\
\qquad T_{a}=\frac{T_{0}}{2} \rightarrow[00] \\
T_{b}=\frac{T_{2}}{2} \rightarrow[01] \\
T_{c}=\left(T_{\mathbf{1}}+\frac{T_{\mathbf{2}}}{2}+\frac{T_{\mathbf{0}}}{2}\right) \rightarrow[1] \\
\text { Sector III }\left(120^{\circ}-180^{\circ}\right)\end{array}$ & $\begin{array}{l}T_{1}=\frac{\sqrt{3}}{\pi} M T_{s} \sin \left(\frac{\pi}{3}-\alpha\right) \\
T_{2}=\frac{\sqrt{3}}{\pi} M T_{s} \sin (\alpha) \text { and } \\
T_{0}=\frac{T_{s}}{2}-T_{1}-T_{2} \\
\text { The duration states and } \\
\text { switching states are: } \\
T_{a}=\left(T_{1}+\frac{T_{2}}{2}+\frac{T_{0}}{2}\right) \rightarrow[00] \\
T_{b}=\frac{T_{2}}{2} \rightarrow\left[\begin{array}{ll}1 & 0\end{array}\right] \\
T_{c}=\frac{T_{0}}{2} \rightarrow[11]\end{array}$ \\
\hline & {$\left[\left(300^{\circ}-360^{\circ}\right)\right.$} \\
\hline
\end{tabular}

$$
\begin{aligned}
& T_{1}=\frac{\sqrt{3}}{\pi} M T_{s} \sin \left(\frac{\pi}{3}-\alpha\right) T_{1}=\frac{\sqrt{3}}{\pi} M T_{s} \sin \left(\frac{\pi}{3}-\alpha\right) ; \\
& T_{2}=\frac{\sqrt{3}}{\pi} M T_{s} \sin (\alpha) \text { and } \\
& T_{0}=\frac{T_{s}}{2}-T_{1}-T_{2} \\
& T_{2}=\frac{\sqrt{3}}{\pi} M T_{s} \sin (\alpha) \text { and } \\
& T_{0}=\frac{T_{s}}{2}-T_{1}-T_{2} \\
& T_{a}=\left(\frac{T_{0}}{2}+\frac{T_{2}}{2}\right) \rightarrow[00] \\
& T_{b}=\left(\frac{T_{1}}{2}+\frac{T_{2}}{2}\right) \rightarrow\left[\begin{array}{ll}
0 & 1
\end{array}\right] \quad T_{c}=\left(\frac{T_{2}}{2}+\frac{T_{0}}{2}\right) \rightarrow[11] \\
& T_{c}=\left(\frac{T_{1}}{2}+\frac{T_{0}}{2}\right) \rightarrow[11] \\
& \begin{array}{l}
T_{a}=\left(\frac{T_{1}}{2}+\frac{T_{0}}{2}\right) \rightarrow[00] \\
T_{b}=\left(\frac{T_{1}}{2}+\frac{T_{2}}{2}\right) \rightarrow\left[\begin{array}{ll}
1 & 0
\end{array}\right] \\
T_{c}=\left(\frac{T_{2}}{2}+\frac{T_{0}}{2}\right) \rightarrow[11]
\end{array}
\end{aligned}
$$

Fig. 9 to Fig. 11 shows the simulation results of induction motor using SSVPWM topology. The applied ac voltage is $450 \mathrm{~V}$, frequency is $50 \mathrm{~Hz}$ and modulation index is 0.9.The parameters of motor as the same for previous simulation. Fig. 9 shows the performance of motor (the three phase load current, the voltage across phase "a", the speed of motor, motor torque and load torque) under constant load torque equal 10Nm. Fig. 10 shows the flux and the relationship between the flux in d- and q- axes. Fig. 11 shows the spectrum analysis for the stator voltage and current. The results show voltage THD is $4.1543 \%$ and current THD is $3.624 \%$, those values are acceptable for IEEE stander.
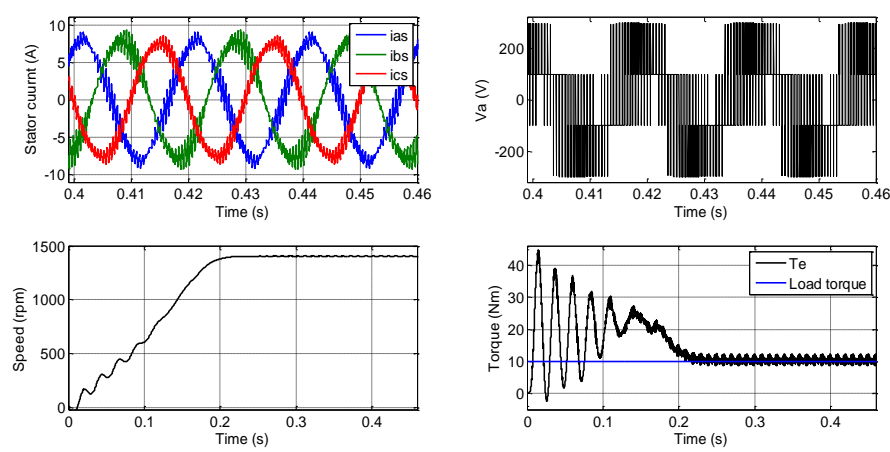

Fig. 6 The performance of motor with load torque is $10 \mathrm{Nm}$ for FSVPWM topology. 

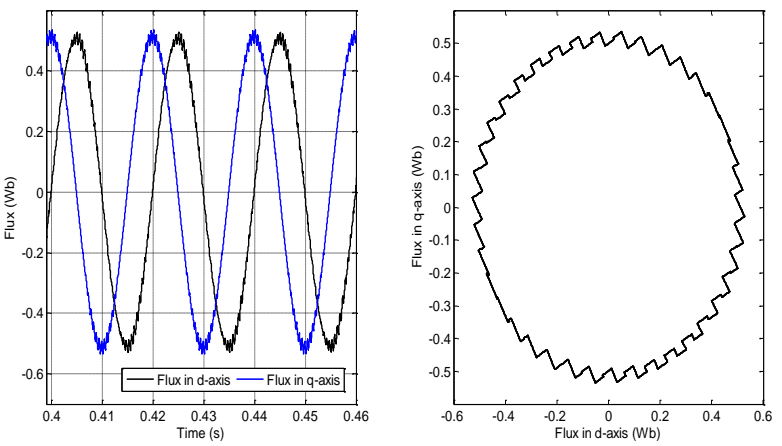

Fig. 7 The stator flux of motor with load torque $10 \mathrm{Nm}$ for FSVPWM topology.
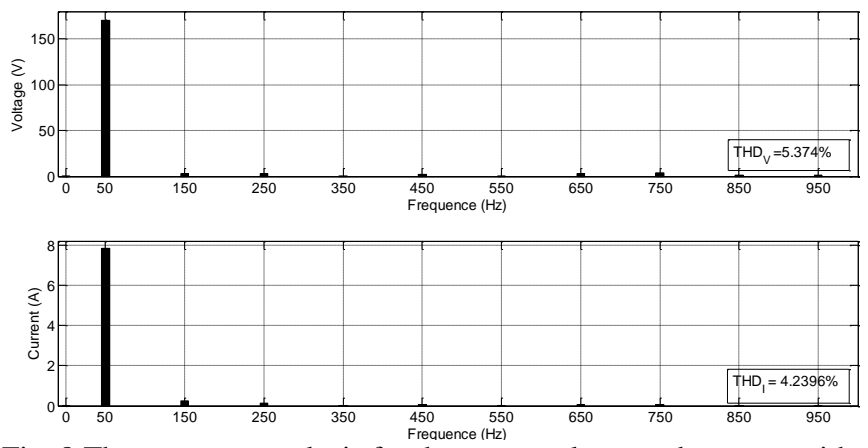

Fig. 8 The spectrum analysis for the stator voltage and current with load torque 10Nm for FSVPWM topology.
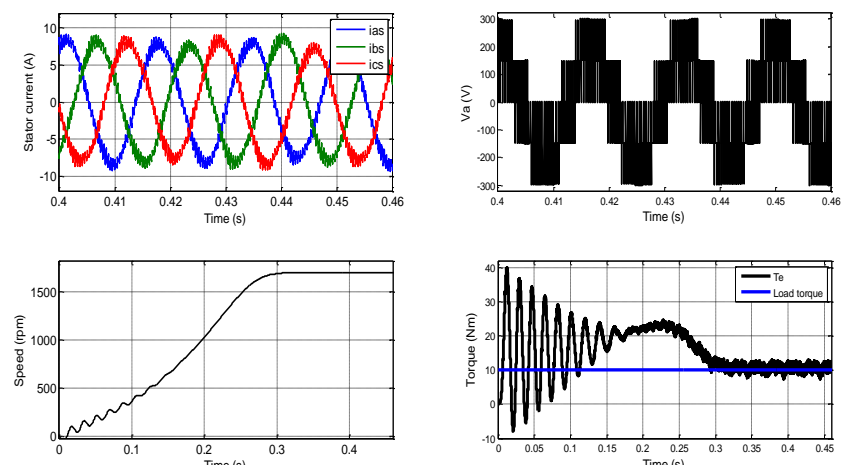

Fig. 9The performance of motor with load torque is $10 \mathrm{Nm}$ for SSVPWM topology.
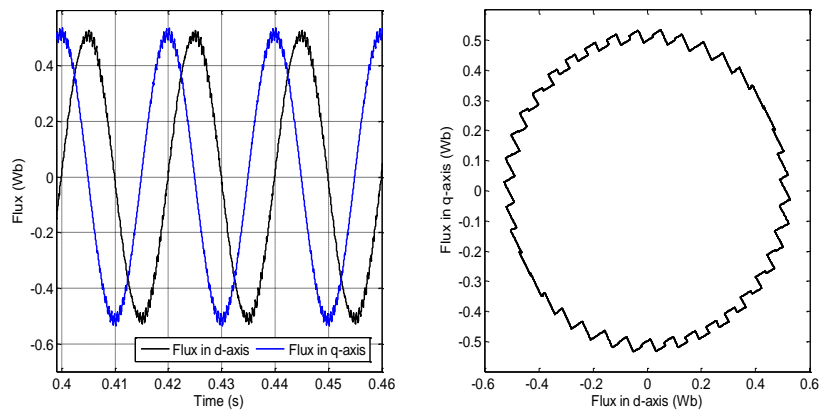

Fig. 10 The stator flux of motor with load torque $10 \mathrm{Nm}$ for SSVPWM topology.
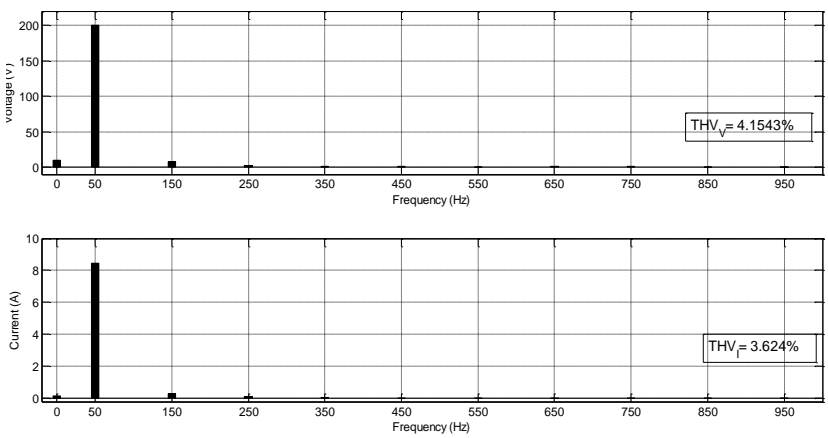

Fig. 11 The spectrum analysis for the stator voltage and current with load torque 10Nm for FSVPWM topology.

Table IV shows the comparison between the SSVPWM and FSVPWM. From this table, when the applied ac voltage of FSVPWM $75 \%$ of SSVPWM, the motor consumes power around $92.3 \%$ when the motor run with SSVPWM for the same load torque and modulation index.

\section{Table IV The Comparison between SSVPWM and FSVPWM.}

\begin{tabular}{|l|l|l|l|}
\hline Quantity & SSVPWM & FSVPWM & $\begin{array}{l}\text { FSVPWM/ } \\
\text { SSVPWM }\end{array}$ \\
\hline $\begin{array}{l}\text { Applied ac } \\
\text { V }\end{array}$ & $450 \mathrm{~V}$ & 600 & 0.75 \\
\hline $\begin{array}{l}\text { Motor rms } \\
\text { V }\end{array}$ & $200 \mathrm{~V}$ & $170 \mathrm{~V}$ & 0.85 \\
\hline $\begin{array}{l}\text { Motor rms } \\
\text { I }\end{array}$ & $8.45 \mathrm{~A}$ & $7.84 \mathrm{~A}$ & 0.92 \\
\hline Speed & $1600 \mathrm{rpm}$ & $1477 \mathrm{rpm}$ & 0.9 \\
\hline $\begin{array}{l}\text { Output } \\
\text { power }\end{array}$ & $1675.5 \mathrm{~W}$ & $1546.7 \mathrm{~W}$ & 0.923 \\
\hline THD $_{\mathrm{V}}$ & $4.1543 \%$ & $5.374 \%$ & 1.293 \\
\hline $\mathrm{THD}_{\mathrm{I}}$ & $3.624 \%$ & $4.239 \%$. & 1.17 \\
\hline
\end{tabular}

\section{CONCLUSIONS}

This paper presented a modified PWM using only four switches that can used in low power applications. The proposed system shows good agreement between the SSVPWM and FSVPWM topologies. Where the voltage and current THD for SSVPWM are $4.1543 \%$ and $3.624 \%$ respectively and voltage and current THD for SSVPWM are $5.374 \%$ and $4.239 \%$. Those values of THD are acceptable. The power consumed of the proposed system is about 0.923 as compared with SSVPWM. 


\section{REFERENCES}

[1] H. W. Van Der Brffick and J. D. Van Wyk, "A comparative investigation of a three-phase induction machine with a component minimized voltage-fed inverter under different control options," IEEE Trans. Ind. Appl., vol. IA-20, no. 2, pp. 309-320, Mar./Apr., 1984.

[2] H. W. Van Der Broeck and H. C. Skudelny, "Analytical analysis of the harmonic effects of a PWM ac drive," IEEE Trans, Power Elec., vol. PE-3, no. 2, pp. 216-223, Apr., 1988.

[3] A. L. OrilleFdez., G. M. A. Sowilam and R. Bargalló,"A generalized control scheme for voltage source PWM vector controller", 5 as Jornadas HispanoLusas de IngenieríaEléctrica del 3 al 5 de Julio de 1997, Salamana (España), Vol I, P.P 269-276.

[4] P. N. Enjeti and A. Rahman, "A new single-phase to three-phase converter with active input current shaping for low cost ac motor drives," IEEE Trans. 2nd. Appl., vol. IA-29, no. 4, pp. 806-813, Jul./Aug., 1993.

[5] P. N. Enjeti, A. Rahman, and R. Jakkli, "Economic single-phase to three-phase converter topologies for fuced and variable frequency output," IEEE Trans. Power Elec., vol. PE-8, no. 3, pp. 329-335, Jul., 1993.

[6] G. A. Covic, G. L. Peters and J. T. Boys, "An improved single phase to three phase converter for low cost ac motor drive," PRM. of Int. Con. on Power Electronics and Drive Systems, Singapore, pp. 549554, 1995.

[7] G. T. Kim and T. A. Lipo, "VSI-PWM rectifier Inverter system with a reduced switch count," IEEE Trans. Ind. Appl., vol. IA-32, no. 6, pp. 1331-1337. Nov./Dec., 1996.

[8] F. B.'Biaabjerg, D. Neacsuand'L K. Pedersen, "Adaptive SVM to compensate dc link voltage ripple for component minimized voltage source inverter," Proc. on IEEE PESC, pp. 580-589, 1997.

[9] D. T. W. Liang and J. Li, "Flux vector strategy for a four-switch three-phase inverter for motor drive application," Proc. on IEEE PESC, pp. 612-617, 1997. [10] M. NasirUddin , T. S, Radwan and M. A. Rahman, "A cost effective 4-switch, 3-phase inverter fed PM motor drive," ICECE 2004, 28-30 dec, 2004, dhaka, Bangladesh, pp. 339-342.

[11] J. klima, "Analytical investigation of an induction motor fed fron four-switch VSI with a new space vector modulation strategy", IEEE Trans. on energy conversion, Vol. 21, No. 4, december 2006, pp. 832838 .

[12] MohmedAzab and A. L. Orille," Novel flux and torque control of induction motor drive using four switch three phase inverter," ICECON'01, the $27^{\text {th }}$ annual conference of the IEEE industrial electronics society, 2004, pp. 1268-1273.

[13] H. H. Lee, P. Q. Dzung, L. M. Phuong, L. D. Khoa and H. T. Thanh, " New space vector control approach for four switch three phase inverter under DC-link voltage ripple", ICSET 2008, pp. 1059-1064.

[14] F. Blaabjerg, S. Freysson, H. H Hansen and S. Hansen,"A new optimized space-vector modulation strategy for a component-minimized voltage source inverter", IEEE Trans. on Power Electronics, Vol. 12, No. 4, July 1997, pp 704-710.

[15] S. M. W Ahmed, G. M. A. Sowilam, M. F. Abd El-kader, "Comparison study between three-phase three-level inverter techniques", The tenth international middle east power systems conference, MEPCON'2005, Dec.13-15, 2005, Port Said, Suez Canal University, Vol. I, PP. 353-362.

[16] S. M. W Ahmed, G. M. A. Sowilam, M. F. Abd El-kader, "Microcontroller based control unit of space vector PWM for a three level inverter fed induction motor drive", MEPCON'2005, Dec.13-15, 2005, Port Said, Suez Canal University, Vol. I, PP. 362-370.

[17] P. Q. Dzung, Le M. Phuong, P. Q. Vinh, N. M. Hoang, T. C. Binh,"New space vector control approach for four switch three phase inverter(FSTPI)", $7^{\text {th }}$ International conference on Power Electronics and drive system 2007. PEDS'07.

\section{Appendix I}

The parameter of Induction motor:

\begin{tabular}{|c|c|c|}
\hline Parameter & symbol & Value \\
\hline Rated power & $\mathrm{P}$ & $4 \mathrm{~kW}$ \\
\hline Rated voltage & $\mathrm{V}$ & $400 \mathrm{~V}$ \\
\hline Rated frequency & $\mathrm{F}$ & $50 \mathrm{~Hz}$ \\
\hline Rated speed & $\mathrm{N}$ & $1430 \mathrm{rpm}$ \\
\hline No. of poles & $\mathrm{p}$ & 4 pole \\
\hline Stator resistance & $\mathrm{R}_{\mathrm{s}}$ & $1.405 \Omega$, \\
\hline $\begin{array}{c}\text { Stator leakage } \\
\text { inductance }\end{array}$ & $\mathrm{L}_{\mathrm{ls}}$ & $0.005839 \mathrm{H}$ \\
\hline Rotor resistance & $\mathrm{R}_{\mathrm{r}}$ & $1.395 \Omega$ \\
\hline $\begin{array}{c}\text { Rotor leakage } \\
\text { inductance }\end{array}$ & $\mathrm{L}_{\mathrm{lr}}$ & $0.005839 \mathrm{H}$ \\
\hline Mutual inductance & $\mathrm{L}_{\mathrm{m}}$ & $0.1722 \mathrm{H}$ \\
\hline Moment of inertia & $\mathrm{J}$ & $0.13 \mathrm{kgm}$ \\
\hline Friction coefficient & $\mathrm{B}$ & $0.002985 \mathrm{Nms}$ \\
\hline
\end{tabular}

